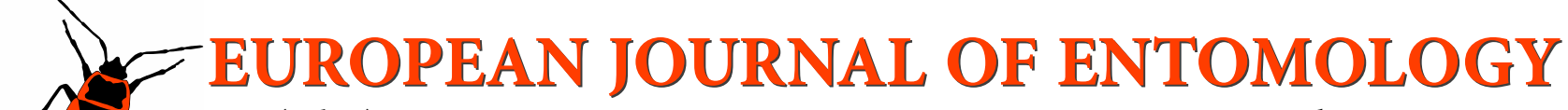 \\ ISSN (online): 1802-8829 \\ http://www.eje.cz \\ Eur. J. Entomol. 115: 332-338, 2018 \\ doi: 10.14411/eje.2018.033 \\ ORIGINAL ARTICLE
}

\section{Dinocampus coccinellae (Hymenoptera: Braconidae) utilizes both Coccinellini and Chilocorini (Coleoptera: Coccinellidae: Coccinellinae) as hosts in Kashmir Himalayas}

\author{
Amir MAQBOOL ${ }^{1}$, Imtiaz AHMED ${ }^{2}$, PIOtr KIEŁTYK ${ }^{3}$ and PIOtr CERYNGIER ${ }^{3}$ \\ ${ }^{1}$ Department of Zoology, Government College for Women, M.A. Road Srinagar - 190001, Jammu and Kashmir, India; \\ e-mail: amaqbool@uok.edu.in \\ 2 P.G. Department of Zoology, University of Kashmir, Hazratbal Srinagar - 190006, Jammu and Kashmir, India; \\ e-mail: drimtiazkuzoo@gmail.com \\ ${ }^{3}$ Faculty of Biology and Environmental Sciences, Cardinal Stefan Wyszyński University, Wóycickiego 1/3, 01-938 Warsaw, \\ Poland; e-mails: p.kieltyk@uksw.edu.pl, p.ceryngier@uksw.edu.pl
}

Key words. Hymenoptera, Braconidae, Dinocampus coccinellae, Coleoptera, Coccinellidae, Oenopia conglobata, Priscibrumus uropygialis, parasitoid, host selection, host suitability

\begin{abstract}
Dinocampus coccinellae is a parasitoid wasp usually parasitizing ladybird beetles of the tribe Coccinellini. A field survey conducted between March and November 2016 revealed three hosts of this parasitoid in the Srinagar district of the Indian state of Jammu and Kashmir: two members of the Coccinellini (Oenopia conglobata and Coccinella undecimpunctata) and one of the Chilocorini (Priscibrumus uropygialis). Proportion of the latter (atypical) host that were parasitized was 0.09 and intermediate between that recorded for $C$. undecimpunctata (0.06) and $O$. conglobata (0.14). A series of laboratory experiments revealed that while a member of Coccinellini (O. conglobata) was more often attacked by $D$. coccinellae than a member of Chilocorini $(P$. uropygialis), the proportions of each species from which parasitoids emerged did not differ significantly. There were no significant differences between $D$. coccinellae females bred from $O$. conglobata and $P$. uropygialis, with respect to selection of the two host species and their suitability for the development of the parasitoid. However, members of the Chilocorini other than $P$. uropygialis (Chilocorus infernalis and Simmondsius pakistanensis) were rarely attacked by D. coccinellae and parasitoid larvae did not emerge from any of those attacked. The results of our experiments indicate that in Kashmir Himalayas $D$. coccinellae is adapted to parasitize hosts belonging to both Coccinellini and Chilocorini.
\end{abstract}

\section{INTRODUCTION}

The cosmopolitan wasp Dinocampus coccinellae (Schrank) is a parasitoid reported to parasitize a variety of ladybird beetles, mostly in the tribe Coccinellini (Ceryngier et al., 2012). Much less often members of Chilocorini are mentioned, including the African Parexochomus troberti concavus (Fürsch) (Hodek, 1973) and the Himalayan Priscibrumus lituratus (Gorham) and P. uropygialis (Mulsant) (Nagarkatti \& Ghani, 1972). As numerous laboratory tests report no response of $D$. coccinellae females to the presence of ladybirds other than those of the Coccinellini (Cushman, 1913; Klausnitzer, 1969; Richerson \& DeLoach, 1972; Ghorpade, 1979), the identity of wasps parasitizing Chilocorini is uncertain (Ceryngier \& Hodek, 1996). However, some recent reports suggest that certain species of Chilocorini can indeed be successfully parasitized by $D$. coccinellae under natural conditions: Mabbott (2006) reports an individual of Exochomus quad- ripustulatus (L.) parasitized by this wasp in Britain, and Minnaar et al. (2014) the parasitization of another member of the genus Exochomus, namely E. flavipes (Thunberg), in South Africa.

Dinocampus coccinellae reproduces by thelytokous parthenogenesis and hence individual strains with selfcontained gene pools and different adaptations may have evolved independently. These adaptations may include the ability to exploit different hosts. Parasitization by D. coccinellae of atypical hosts in the Chilocorini may be an illustration of such adaptations.

In this paper we report that a member of the Chilocorini, Priscibrumus uropygialis (Fig. 1), is regularly parasitized by $D$. coccinellae in the Kashmir Himalayas. In addition to the field data, we present results of laboratory experiments on the host selection behaviour of $D$. coccinellae and suitability of several ladybirds for the development of this parasitoid. 

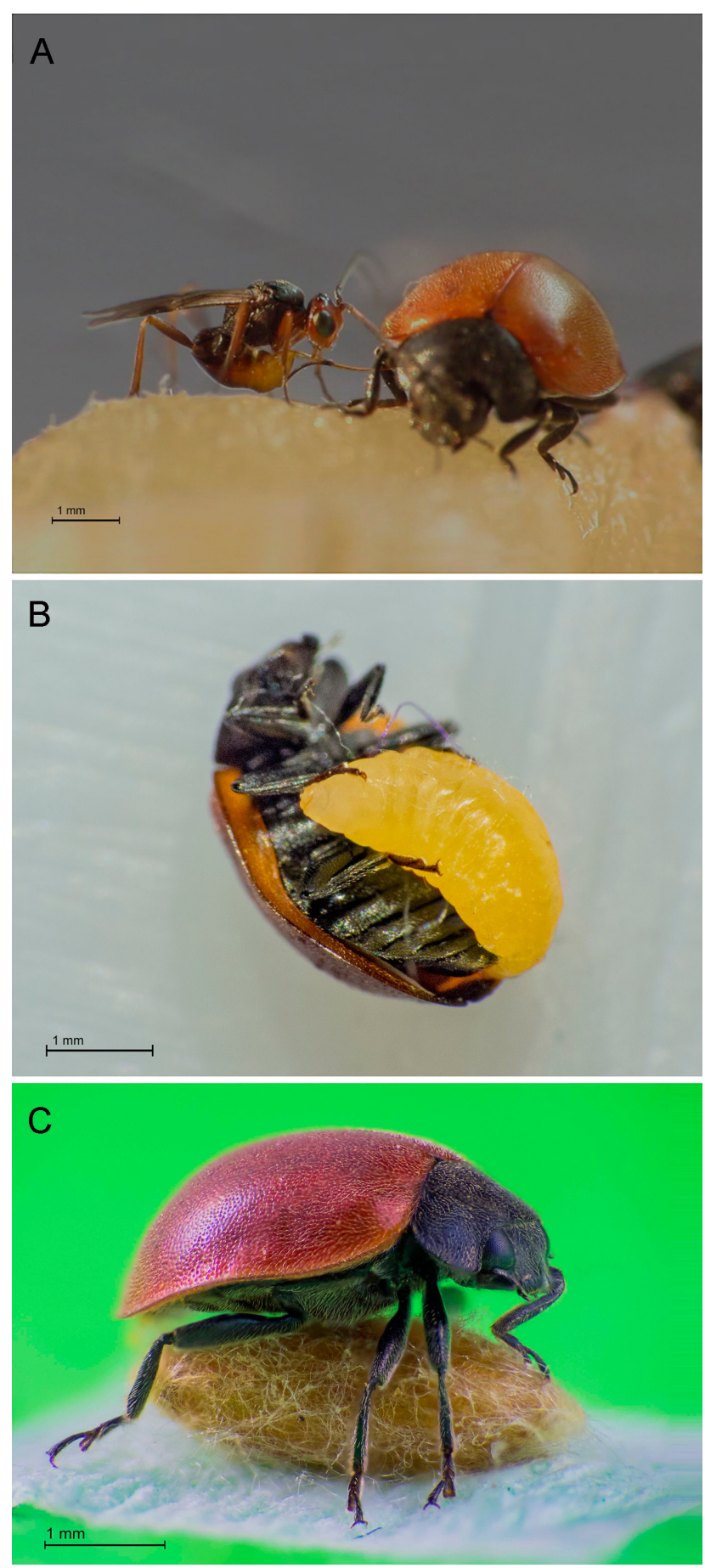

Fig. 1. Priscibrumus uropygialis as a host of Dinocampus coccinellae. A - oviposition, B - emergence of a parasitoid larva, C - host with a parasitoid cocoon between its legs.

\section{MATERIAL AND METHODS}

\section{Parasitism of field collected ladybirds}

Between March and November 2016, adult ladybirds of various species were collected in apple orchards at three sites (Kashmir University Campus $-34.13^{\circ} \mathrm{N}, 74.84^{\circ} \mathrm{E}$, Dara $-34.18^{\circ} \mathrm{N}$, $74.91^{\circ} \mathrm{E}$ and Hyderpora $-34.03^{\circ} \mathrm{N}, 74.79^{\circ} \mathrm{E}$ ) in Srinagar district in the Indian state Jammu and Kashmir (Fig. 2). Individuals with the parasitoid cocoon between their legs, either before emergence of the adult wasp or already empty (after emergence), were noted. The remaining beetles, after transfer to the laboratory, were placed in well ventilated Plexiglas boxes $(20 \mathrm{~cm} \times 15 \mathrm{~cm} \times 5 \mathrm{~cm})$ the bottoms of which were lined with soft tissue paper. Ladybirds of each species were reared in separate boxes with a maximum of 50 individuals per box. They were fed the green apple aphid (Aphis pomi De Geer) on alternate days. In addition, small cotton balls moistened with $10 \%$ honey solution were supplied and remoistened twice a day. The emergence of parasitoids from these ladybirds was checked twice a day for four weeks. The proportion of individuals of a given host species, from which parasitoid larvae emerged was the sum of the hosts collected with cocoons and those giving rise to cocoons in the laboratory divided by the total number of individuals collected.

\section{Laboratory experiments}

A series of experiments in which the frequency with which $D$. coccinellae oviposited in different hosts and their suitability for parasitoid development were carried out in the laboratory at 28.5 $\pm 1^{\circ} \mathrm{C}$ and a $14 \mathrm{~L}: 10 \mathrm{D}$ lighting regime. Females of D. coccinellae used in the experiments were bred either from field collected ladybirds or from those parasitized in the laboratory. In the latter case, ladybirds that were parasitized in the laboratory belonged to the same species as the field collected ladybird, from which the wasp was reared. The wasps were used in the experiments $48 \mathrm{~h}$ after their emergence. Until then they were kept in perforated Eppendorf tubes with a few drops of $10 \%$ honey solution. The ladybirds used in these experiments were those collected in the field and from which parasitoids did not emerge during the 4-week rearing in the laboratory.

Interactions between the experimental insects were recorded in $8 \mathrm{~cm} \times 4 \mathrm{~cm} \times 2 \mathrm{~cm}$ Plexiglas boxes using a video camera for a more accurate analysis of the parasitoid and host behaviour. A single $D$. coccinellae female was placed in the box with a definite number of ladybird adults of one or more species, depending on the experiment (the experimental design is summarized in Table 1). The oviposition by the wasp was recorded for $10 \mathrm{~min}$. After this, each ladybird was placed in a separate Petri dish and reared for three weeks or until a $D$. coccinellae larva emerged. The ladybirds were supplied with aphids (Aphis pomi de Geer) on alternate days and with cotton balls moistened with $10 \%$ honey solution twice a day. In each experiment, the number of ovipositions, number of hosts from which parasitoid larvae emerged and number of hosts giving rise to adult wasps were determined for each ladybird species. Based on these results, the proportion from which parasitoid larvae emerged (number of hosts from which parasitoid larvae emerged divided by number of hosts attacked) and the proportion from which adult parasitoids emerged (number of hosts from which adult parasitoids emerged divided by number of hosts attacked) were calculated. Although $D$. coccinellae is a solitary parasitoid and, hence, only one individual can develop in a single host, superparasitism (multiple ovipositions in a given host) is frequent in this species (Maeta, 1969; Ceryngier, 2000). Females of D. coccinellae oviposit in hosts they have recently parasitized after a short period of host rejection (Okuda \& Ceryngier, 2000). Therefore, we assumed that the oviposition frequency determined in tests using a limited number of hosts (from four to 12 , depending on the experiment) will not be significantly disrupted due to host discrimination by the wasps.

In the no-choice experiments 1 and 2, we investigated if there were any differences in the number of ovipositions and the rate of parasitoid development in two different hosts: a member of Chilocorini (Priscibrumus uropygialis) and a member of Coccinellini (Oenopia conglobata (L.)). The next two experiments (experiments 3 and 4) tested whether wasps given a choice of $P$. uropygialis or $O$. conglobata, preferred to oviposit in a particular species and whether they developed more successfully in 


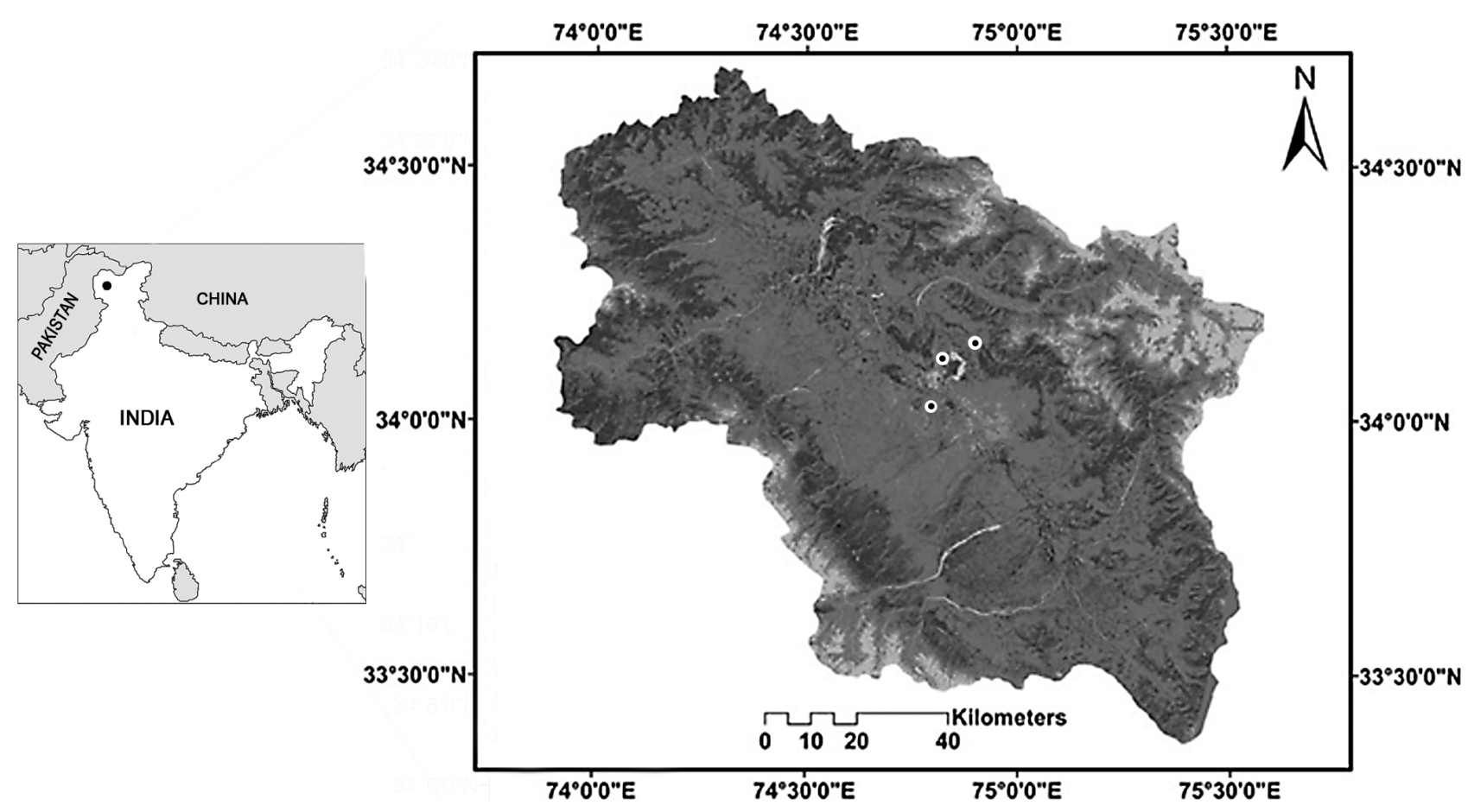

Fig. 2. Geographical location of the ladybird sampling sites in the state of Jammu and Kashmir in India.

the preferred species. Finally, (experiment 5), a wider choice of Chilocorini hosts (P. uropygialis, Chilocorus infernalis and Simmondsius pakistanensis) along with one Coccinellini host $(O$. conglobata) were offered to single wasps. Each experiment was repeated five times.

\section{RESULTS}

\section{Parasitism of field collected ladybirds}

Twelve species of ladybirds were collected in apple orchards in Srinagar district, and from three of them, $P$. uropygialis, Oenopia conglobata and Coccinella undecimpunctata L., larvae of D. coccinellae emerged (Fig. 3). For the pooled results of all samples (Fig. 4), the proportion of $O$. conglobata $(0.14)$ parasitized was significantly greater than that of $P$. uropygialis (0.09) (chi-squared test: $\left.\chi^{2}=4.76, \mathrm{df}=1, \mathrm{p}=0.03\right)$. The proportion of $C$. undecimpunctata from which larvae emerged (0.06), although even lower than that from $P$. uropygialis, was not significantly different from that recorded for the remaining two host species due to the low number of $C$. undecimpunctata collected. No parasitoids emerged from Chilocorus infernalis Mulsant ( $\mathrm{N}=101)$, Platynaspidius saundersi (Crotch) $(\mathrm{N}$ = 54), Pharoscymnus flexibilis kashmirensis Kapur ( $\mathrm{N}=$ 44), Simmondsius pakistanensis Ahmad \& Ghani ( $\mathrm{N}=41)$, Stethorus gilvifrons (Mulsant) $(\mathrm{N}=38)$, Harmonia eucha- ris (Mulsant) ( $\mathrm{N}=17)$, Coccinella septempunctata $\mathrm{L} .(\mathrm{N}$ $=8)$, Aiolocaria hexaspilota (Hope) $(\mathrm{N}=5)$ and Adalia tetraspilota (Hope) $(\mathrm{N}=4)$.

\section{Laboratory experiments}

Comparison of the results of the no-choice experiments 1 and 2 (Fig. 5) indicate that $O$. conglobata is attacked by $D$. coccinellae more frequently than $P$. uropygialis. However, the proportion of the attacked individuals of each species from which parasitoid larvae and adults emerged did not differ significantly (proportion of $O$. conglobata from which larvae emerged was 0.63 and from $P$. uropygialis it was 0.53 , chi-squared test: $\chi^{2}=0.334, \mathrm{df}=1, \mathrm{p}=0.56$; proportion of $O$. conglobata from which adults emerged was 0.63 and from $P$. uropygialis it was 0.47 , chi-squared test: $\left.\chi^{2}=0.925, \mathrm{df}=1, \mathrm{p}=0.34\right)$.

The experiments 3 and 4 , where $D$. coccinellae females had a choice between two species, again showed that $O$. conglobata was more frequently attacked than $P$. uropygialis (Fig. 6), while the differences in the proportions from which parasitoids emerged were low and statistically insignificant (proportion of $P$. uropygialis from which larvae emerged was 0.47 and from $O$. conglobata it was 0.54 , chisquared test: $\chi^{2}=0.196, \mathrm{df}=1, \mathrm{p}=0.66$; proportion of $P$. uropygialis from which adults emerged was 0.47 and from

Table 1. Experimental design used in this study. Wasp origin - ladybird species, from which the wasp used in the experiment was bred.

\begin{tabular}{llccc} 
& Wasp origin & \multicolumn{3}{c}{ Number of ladybirds offered to a single wasp } \\
\cline { 3 - 5 } & & P. uropygialis & O. conglobata & C. infernalis \\
\hline Experiment 1 & P. uropygialis & 4 & - & - \\
Experiment 2 & O. conglobata & - & 4 & - \\
Experiment 3 & P. uropygialis & 3 & 3 & - \\
Experiment 4 & O. conglobata & 3 & 3 & - \\
Experiment 5 & P. uropygialis & 3 & 3 & - \\
\hline
\end{tabular}



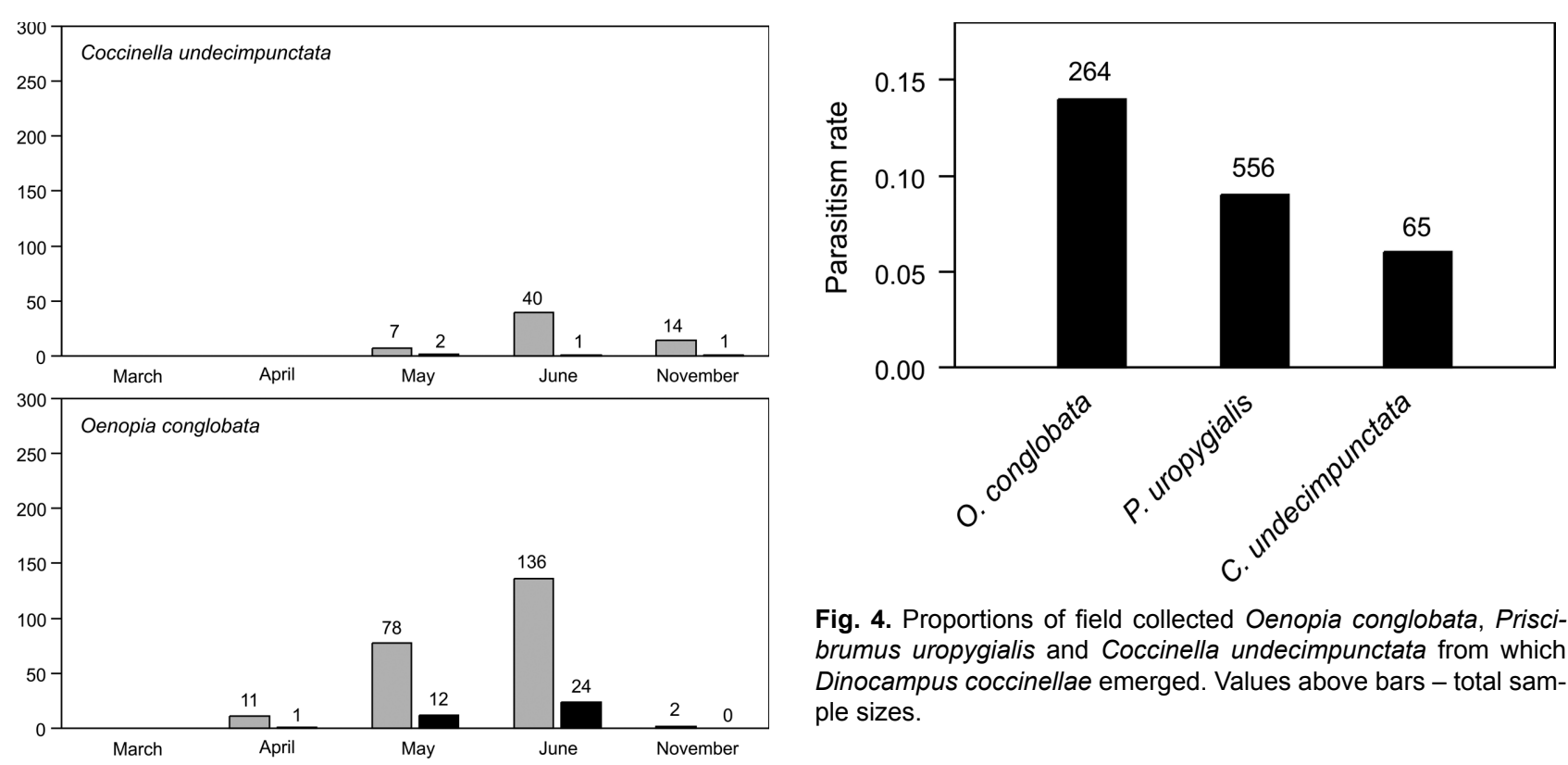

Fig. 4. Proportions of field collected Oenopia conglobata, Priscibrumus uropygialis and Coccinella undecimpunctata from which Dinocampus coccinellae emerged. Values above bars - total sample sizes.

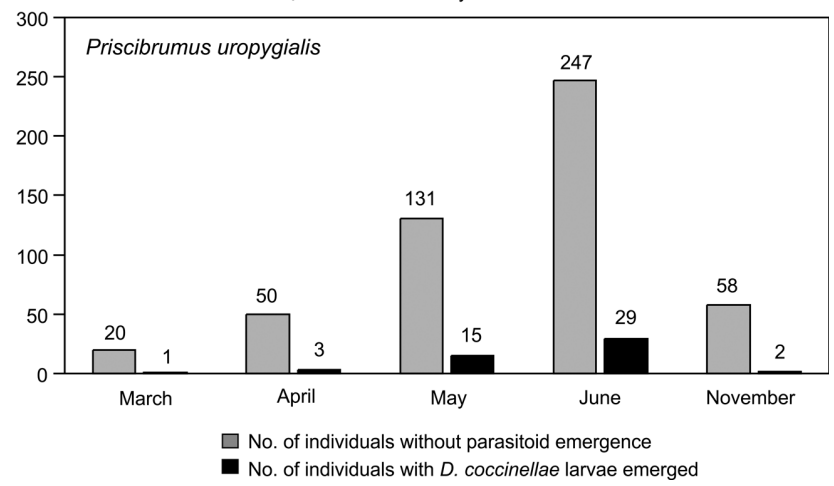

When caged with ladybirds belonging to four different species (experiment 5), D. coccinellae females still more frequently attacked $O$. conglobata than $P$. uropygialis. The remaining two ladybirds ( $C$. infernalis and $S$. pakistanensis) were rarely attacked (Fig. 7). In contrast to what was recorded in the previous tests, proportions of emergence of $D$. coccinellae larvae and adults from $P$. uropygialis were much (more than twice) lower than those from $O$. conglobata, although the difference was not significant (proportion of $P$. uropygialis from which larvae emerged was 0.25 and from $O$. conglobata it was 0.60 , chi-squared test: $\chi^{2}=$ $2.205, \mathrm{df}=1, \mathrm{p}=0.14$; the same proportions were recorded for adult emergence).

Fig. 3. Numbers of individuals of field collected Coccinella undecimpunctata, Oenopia conglobata and Priscibrumus uropygialis from which one or no larvae of Dinocampus coccinellae emerged. Values above bars - numbers of individuals.

O. conglobata it was 0.50 , chi-squared test: $\chi^{2}=0.042, \mathrm{df}=$ $1, \mathrm{p}=0.84)$. The wasps bred from different host species $(P$. uropygialis or $O$. conglobata) did not differ significantly in terms of their host selectivity (frequency of ovipositions in individual host species) or host suitability (proportions that emerged from individual host species).
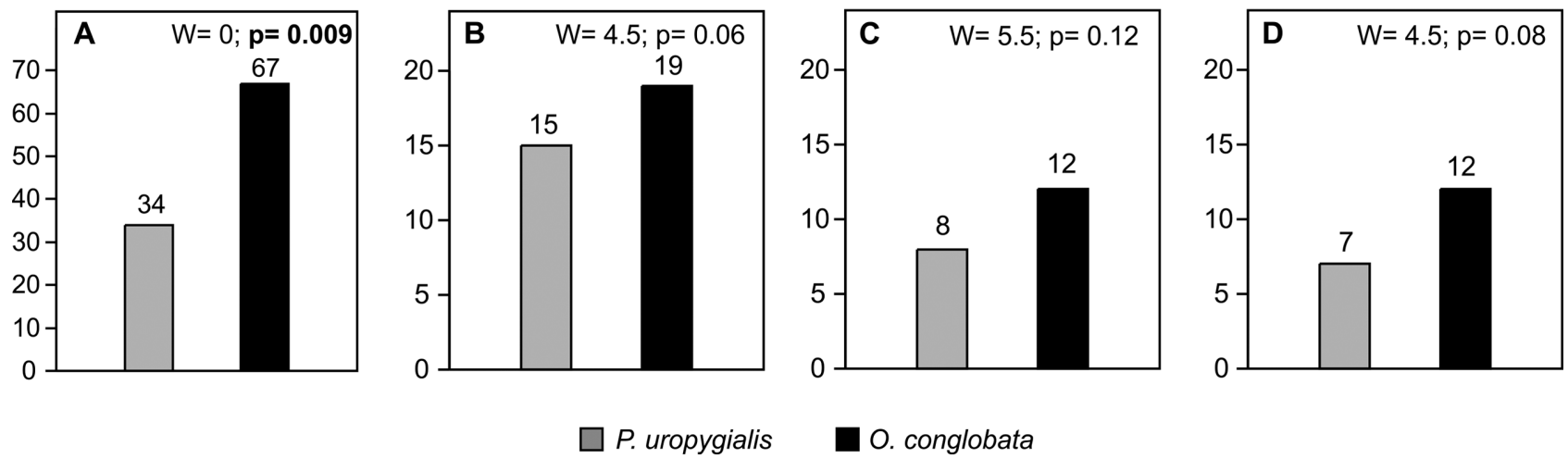

Fig. 5. Summary of the results of the no-choice experiments. The number of ovipositional attacks and development of Dinocampus coccinellae in either four individuals of Priscibrumus uropygialis or four individuals of Oenopia conglobata. Pooled results of five replicates (20 individuals) per host species. Differences between host species tested using the Wilcoxon rank-sum test. A - total number of attacks, B - number of hosts attacked, C - number of larvae that emerged, D - number of adults that emerged. 
D. coccinellae origin: $P$. uropygialis
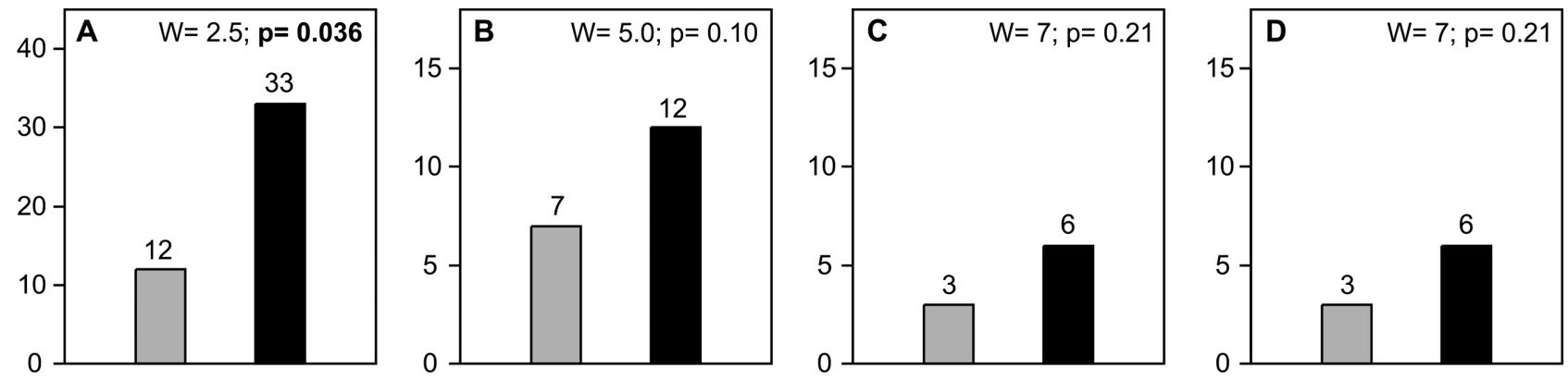

D. coccinellae origin: $O$. conglobata
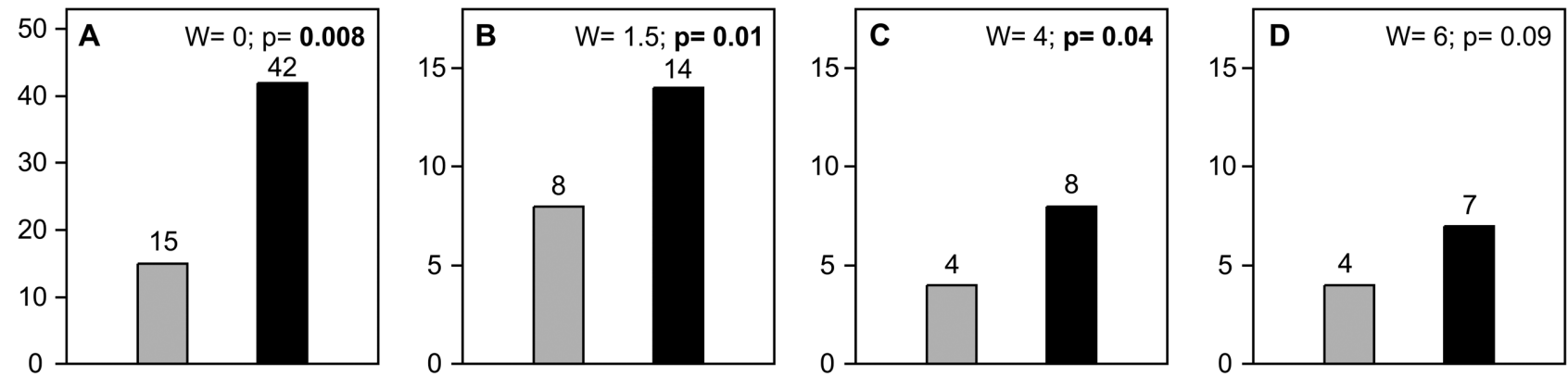

Data pooled
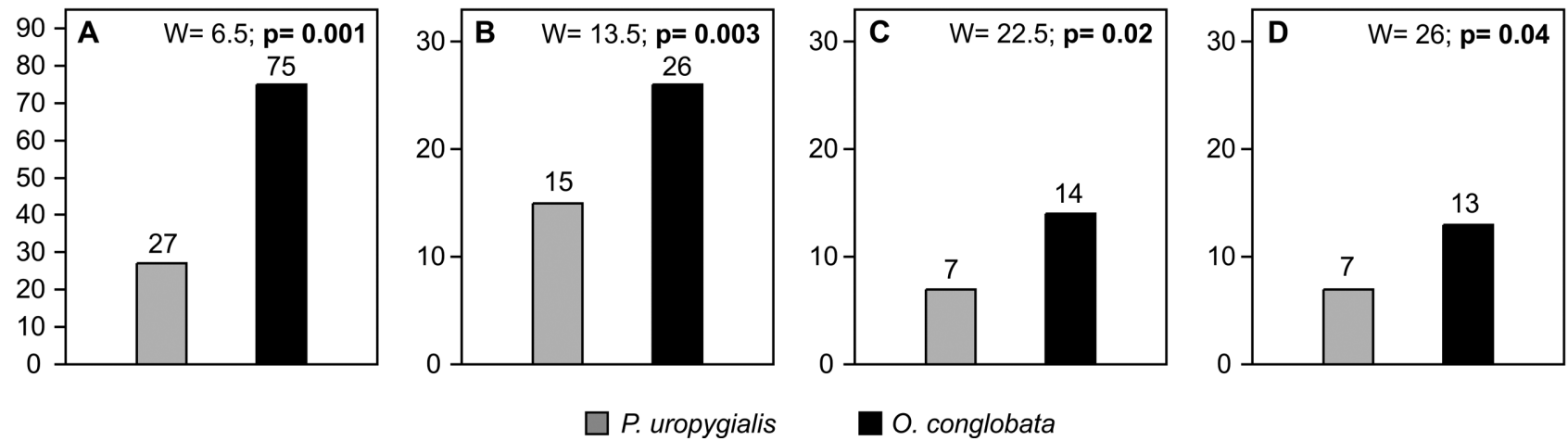

P. uropygialis

Fig. 6. Summary of the results of experiments in which the number of ovipositions and the number resulting in the development of Dinocampus coccinellae in three individuals each of Priscibrumus uropygialis and Oenopia conglobata presented together. Pooled results of five replicates ( $15 \mathrm{P}$. uropygialis and $15 \mathrm{O}$. conglobata) in the two upper rows and of 10 replicates ( $30 \mathrm{P}$. uropygialis and $30 \mathrm{O}$. conglobata) in the lowest row. Differences between host species tested using the Wilcoxon rank-sum test. A-D - as in Fig. 5.
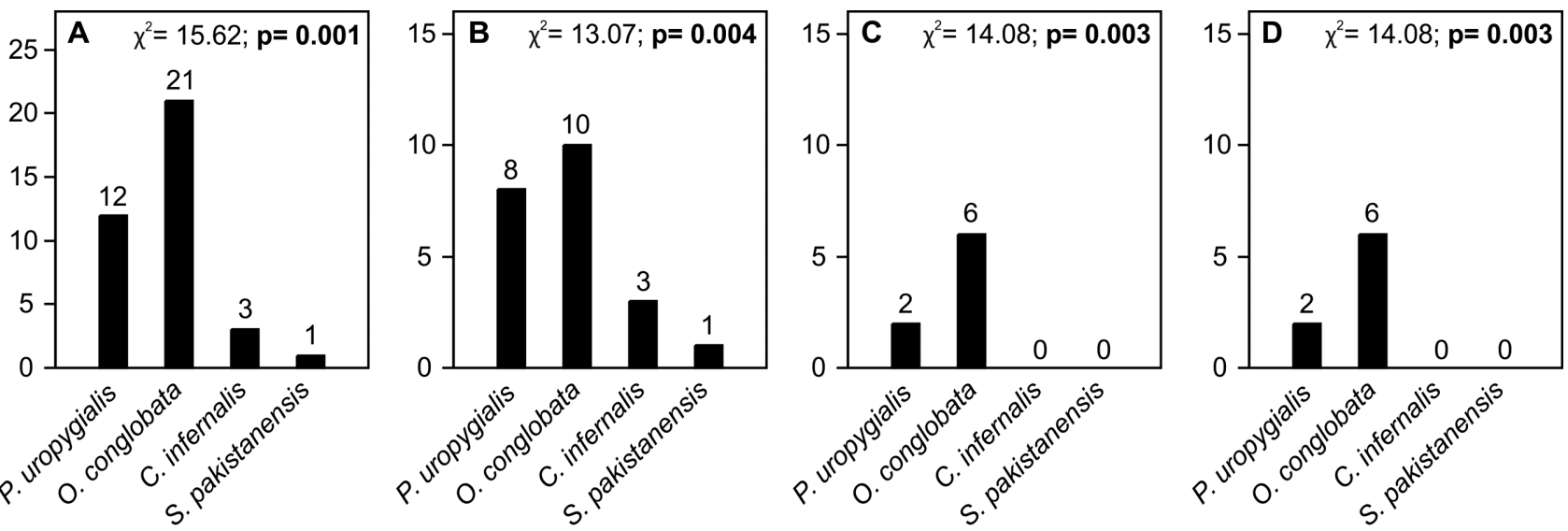

Fig. 7. Summary of the results of the experiment testing the number of ovipositions and the number resulting in the development of Dinocampus coccinellae in three individuals of each of Priscibrumus uropygialis, Oenopia conglobata, Chilocorus infernalis and Simmondsius pakistanensis. Pooled results of five replicates (15 individuals of each species). Differences among host species tested using the KruskalWallis test. A-D - as in Fig. 5. 
In the three species of ladybirds parasitized by $D$. coccinellae the so-called bodyguard behaviour was observed. After the parasitoid larva emerged from the host ladybird it formed a cocoon between host's legs and pupated inside the cocoon, while the ladybird was still alive, but immobilized due to partial paralysis. The paralyzed host guarded the cocoon clasping it with its legs.

\section{DISCUSSION}

Our field survey demonstrates that in Kashmir Himalayas a member of the coccinellid tribe Chilocorini, P. uropygialis, is regularly parasitized by $D$. coccinellae along with at least two members of the Coccinellini, O. conglobata and C. undecimpunctata. A significantly higher proportion of $D$. coccinellae emerged from field-collected $O$. conglobata than $P$. uropygialis, which might be a result of a higher parasitization of $O$. conglobata and/or higher suitability of this species for parasitoid development. The results of our experiments indicate that both these factors are likely to be involved: in all the experiments $O$. conglobata was attacked more frequently than $P$. uropygialis and the proportion that resulted in the emergence of $D$. coccinellae, although not significantly different, was consistently higher when $O$. conglobata was the host.

The differences between the proportions of $P$. uropygialis and $O$. conglobata oviposited in by $D$. coccinellae may not only be due to different host preferences of the parasitoid. Observations made during the experiments indicated that $O$. conglobata is much more mobile than P. uropygialis when confronted with $D$. coccinellae (see video sequences at https://figshare.com/s/4702790b28c002d55318). One of the stimuli involved in the host recognition and acceptance behaviour of $D$. coccinellae is the mobility of the host (Balduf, 1926; Walker, 1961; Richerson \& DeLoach, 1972; Orr et al., 1992), with mobile hosts more often attacked than stationary hosts. Moreover, movement of the host makes the oviposition easier, because the areas into which D. coccinellae usually oviposits (the soft membranes between abdominal sclerites and between the head and thorax) are more exposed in a walking ladybird (Balduf, 1926; Richerson \& DeLoach, 1972). Therefore, ovipositional attacks on highly mobile $O$. conglobata should be more effective than those on the much less active $P$. uropygialis. Indeed, when a parasitoid female attempted to parasitize $P$. uropygialis, it usually had to spend much time stimulating the host to walk by circling around it, palpating it with its antennae and probing with its ovipositor.

Suitability of both, O. conglobata and P. uropygialis, for the development of $D$. coccinellae expressed in terms of successful parasitism (proportion of hosts attacked that resulted in the emergence of adult parasitoids) was not very high (around 0.5), but within the range reported for host species regarded as highly suitable. The successful parasitism of adult Coleomegilla maculata (De Geer), for example, is reported to vary between 0.18 and 0.96 and that of adult Coccinella septempunctata L., between 0. 32 and 0.78 (data of various authors compiled in Ceryngier et al., 2012).
There was no effect of the origin of $D$. coccinellae on their preference for particular species of hosts or on the suitability of different host species for development of their progeny, indicating that in the Kashmir Himalayas this wasp is adapted to parasitize ladybirds belonging to different tribes. The recorded host tribes (Coccinellini and Chilocorini) seem to be closely related, since most of the recent phylogenetic analyses (Magro et al., 2010; Seago et al., 2011; Robertson et al., 2015; Escalona et al., 2017) recognize them as sister groups. A shared parasitoid may be regarded as a further confirmation of this close relationship. Moreover, in both, Coccinellini and Chilocorini, $D$. coccinellae induces the same bodyguard behaviour. Recent research by Dheilly et al. (2015) indicates that this behaviour is probably mediated by a symbiotic virus in $D$. coccinellae called D. coccinellae paralysis virus (DcPV). Our observations indicate that the Coccinellini and Chilocorini hosts are similarly susceptible to DcPV.

There are a few reports that indicate $D$. coccinellae may also occasionally parasitize non-Coccinellini hosts other than Chilocorini. Richerson \& DeLoach (1973) report that $1.8 \%$ of Brachiacantha ursina (Fabricius) (Hyperaspidini) from Missouri (USA) contain larvae of this parasitoid. In the same area and at the same time, the percentage parasitism of eight Coccinellini species, however, was much higher, ranging between $5.1 \%$ and $26.8 \%$. Also the suitability of $B$. ursina for the development of $D$. coccinellae is assessed as rather low in comparison with Coccinellini hosts. Richerson \& DeLoach (1972) bred one adult of $D$. coccinellae from 25 laboratory parasitized B. ursina (4\%), while the percentage of emergence of this parasitoid from six species of Coccinellini was between $12 \%$ and $96 \%$. In New Zealand, D. coccinellae larvae are even sporadically recorded in non-ladybird hosts, such as weevils of the species Sitona discoideus Gyllenhal (Wightman, 1986). Both, $B$. ursina and $S$. discoideus, should be regarded as marginal hosts of $D$. coccinellae with very low suitability for its development, in contrast to the quite suitable $P$. uropygialis.

To conclude, our study provides strong evidence that $D$. coccinellae in Kashmir can successfully parasitize both Chilocorini and Coccinellini ladybirds and that a member of the former tribe, P. uropygialis, is regularly used as a host by this parasitoid. However, further studies are required to elucidate whether $D$. coccinellae from Kashmir and those from other regions in the world are a single species or a species complex.

ACKNOWLEDGEMENTS. We thank two anonymous reviewers for their useful comments and suggestions and A.F.G. Dixon for improving our English.

\section{REFERENCES}

BALduF W.V. 1926: The bionomics of Dinocampus coccinellae Schrank. - Ann. Entomol. Soc. Am. 19: 465-498.

CERYNGIER P. 2000: Overwintering of Coccinella septempunctata (Coleoptera: Coccinellidae) at different altitudes in the Karkonosze Mts, SW Poland. - Eur. J. Entomol. 97: 323-328. Ceryngier P. \& Hodek I. 1996: Enemies of Coccinellidae. In Hodek I. \& Honĕk A. (eds): Ecology of Coccinellidae. Kluwer Acad. Publ., Dordrecht, pp. 319-350. 
Ceryngier P., Roy H.E. \& Poland R.L. 2012: Natural enemies of ladybird beetles. In Hodek I., van Emden H.F. \& Honěk A. (eds): Ecology and Behaviour of the Ladybird Beetles (Coccinellidae). Blackwell, Chichester, pp. 375-443.

Cushman R.A. 1913: Biological notes on a few rare or little known parasitic Hymenoptera. - Proc. Entomol. Soc. Wash. 15: 153-161.

Dheilly N.M., Maure F., Ravallec M., Galinier R., Doyon J., Duval D., Leger L., Volkoff A.-N., Missé D., Nidelet S., Demolombe V., Brodeur J., Gourbal B., Thomas F. \& Mitta G. 2015: Who is the puppet master? Replication of a parasitic wasp-associated virus correlates with host behaviour manipulation. - Proc. R. Soc. Lond. (B) 282: 20142773, 10 pp.

Escalona H.E., Zwick A., Li H.-S., Li J., Wang X., Pang H., Hartley D., Jermin L.S., Nedvěd O., Misof B., Niehuis O., ŚLIPIŃSKI A. \& TOMASZEWSKA W. 2017: Molecular phylogeny reveals food plasticity in the evolution of true ladybird beetles (Coleoptera: Coccinellidae: Coccinellini). - BMC Evol. Biol. 17: $151,11 \mathrm{pp}$.

GHorpade K.D. 1979: Further notes on Perilitus coccinellae (Hymenoptera: Braconidae) in India. - Curr. Res. 8: 112-113.

Hodek I. 1973: Biology of Coccinellidae. Academia, Prague, 260 pp.

KLAuSNITZER B. 1969: Zur Kenntnis der Entomoparasiten mitteleuropäischer Coccinellidae. - Abh. Ber. NaturkMus. Görlitz 44: 1-15.

Mаввотт P.R. 2006: Exochomus quadripustulatus (L.) (Coleoptera: Coccinellidae) as a host of Dinocampus coccinellae (Schrank) (Hymenoptera: Braconidae). - Br. J. Entomol. Nat. Hist. 19: 40.

MAETA Y. 1969: Biological studies on the natural enemies of some coccinellid beetles. I. On Perilitus coccinellae (Schrank). Kontyû 37: 147-166 [in Japanese with English abstr].

Magro A., Lecompte E., Magné F., Hemptinne J.-L. \& CrouauRoY B. 2010: Phylogeny of ladybirds (Coleoptera: Coccinellidae): Are the subfamilies monophyletic? - Mol. Phylogenet. Evol. 54: 833-848.

Minnaar I.A., Shinner R., Van Noort S. \& Clusella-Trullas S. 2014: New records of the parasitic wasp Dinocampus coccinellae (Hymenoptera: Braconidae) and its hosts in South Africa. - Afr. Entomol. 22: 226-229.
Nagarkatti S. \& Ghani M.A. 1972: Coleoptera: Coccinellidae. In Rao V.P. \& Ghani M.A. (eds): Studies on predators of Adelges spp. in the Himalayas. - Misc. Publs Commonw. Inst. Biol. Control no. 3, pp. 58-89.

Okuda T. \& Ceryngier P. 2000: Host discrimination in Dinocampus coccinellae (Hymenoptera: Braconidae), a solitary parasitoid of coccinellid beetles. - Appl. Entomol. Zool. 35: 535-539.

OrR C.J., OBRYCKi J.J. \& Flanders R.V. 1992: Host-acceptance behavior of Dinocampus coccinellae (Hymenoptera: Braconidae). - Ann. Entomol. Soc. Am. 85: 722-730.

Richerson J.V. \& DeLoach C.J. 1972: Some aspects of host selection by Perilitus coccinellae. - Ann. Entomol. Soc. Am. 65: 834-839.

Richerson J.V. \& DeLoach C.J. 1973: Seasonal abundance of Perilitus coccinellae and its coccinellid hosts and degree of parasitism in central Missouri. - Environ. Entomol. 2: 138 141.

Robertson J.A., Ślipiński A., Moulton M., Shockley F.W., GiorGi A., Lord N.P., McKenna D.D., TomaszewsKa W., Forrester J., Miller K.B., Whiting M.F. \& McHugh J.V. 2015: Phylogeny and classification of Cucujoidea and the recognition of a new superfamily Coccinelloidea (Coleoptera: Cucujiformia). — Syst. Entomol. 40: 745-778.

Seago A.E., Giorgi J.A., Li J. \& Ślipiński A. 2011: Phylogeny, classification and evolution of ladybird beetles (Coleoptera: Coccinellidae) based on simultaneous analysis of molecular and morphological data. - Mol. Phylogenet. Evol. 60: 137151.

WALKeR M.F. 1961: Some observations on the biology of the ladybird parasite Perilitus coccinellae (Schrank) (Hym., Braconidae), with special reference to host selection and recognition. —Entomol. Mon. Mag. 97: 240-244.

Wightman J.A. 1986: Sitona discoideus (Coleoptera: Curculionidae) in New Zealand, 1975-1983: distribution, population studies, and bionomic strategy. - N. Z. J. Zool. 13: 221-240.

Received February 10, 2018; revised and accepted May 9, 2018 Published online July 10, 2018 